\title{
New Tacrine derivatives and Tacrine-Chitosan systems to its application against degenerative diseases
}

\author{
Antonio J. Galera-Carrillo, Antonio Franconetti-García, Francisca Cabrera-Escribano
}

Departamento de Química Orgánica, Facultad de Química, Universidad de Sevilla, Apartado de Correos No. 1203, 41071 Sevilla, Spain. Fax: +34954624960; Tel: +34954556868;

E-mail: agalera@us.es

\begin{abstract}
Our research focuses on the synthesis of new tacrine derivatives with an expected similar or higher inhibitory activity of AChE and BuChE than commercial tacrine and hybrids tacrine-chitosan derivatives with tunable biological properties by reaction of the biopolymer with the different tacrine derivatives synthesized. All new compounds have been characterized by NMR techniques both in solution and in solid state.
\end{abstract}

\section{Keywords}

Chitosan; Tacrine; AChE; Hybrids tacrine-chitosan

\section{Introduction}

Chitosan is a natural non-toxic, biodegradable and biocompatible polymer, which is derived from chitin, whose structure allows a wide variety of chemical modifications that can confer new physical-chemical properties, functions and applications in different fields. $^{1,2}$

Among the great challenges facing the Society is the search for solutions to Alzheimer's disease. This disease presents high cellular oxidative stress, as a result of the imbalance between the oxidizing species generated in the cells and antioxidant compounds. ${ }^{3}$ One of the strategies used in the treatment of Alzheimer's disease is based on the use of acetylcholinesterase (AChE) inhibitors, an enzyme that catalyzes the hydrolysis of acetylcholine, a neurotransmitter involved in memory. In this context, 
tacrine was the first drug approved for this purpose, later withdrawn due to liver damage caused by inducing oxidative stress. ${ }^{4}$

In the present work, new Tacrine derivatives that reduce the original hepatotoxicity of the compound while preserving its properties as an AChE inhibitor have been prepared and characterized. Furthermore, new hybrid systems Tacrine-Chitosan have been synthesized and characterized in order to serve as a vector of the drug in the human body by the formation of different bridges between Tacrine and Chitosan. Moreover, the reduction of oxidative stress through the presence of a bridge of selenourea type among the same molecules, given the property of Se to reduce the number of ROS species in the cell.

\section{Experimental Methods}

All chemicals were purchased and used without further purification. Evaporations were conducted under reduced pressure. TLC was performed on silica gel plates (MN ALUGRAM Xtra SIL G/UV 254). All new compounds were synthesized following the below general procedure. Detection of compounds was accomplished with UV light $(254 \mathrm{~nm})$ and by charring with $\mathrm{H}_{2} \mathrm{SO}_{4}$ and characterization by ${ }^{1} \mathrm{H}$ and ${ }^{13} \mathrm{C}$ NMR, ${ }^{13} \mathrm{C}$ CPMAS NMR spectroscopy and Mass spectrometry.

\section{Example of tacrine derivative synthesis:}

\section{$N$-(1,2,3,4-tetrahydroacridin-9-yl)ethane-1,2-diamine}

A mixture of (9-Chloro-1,2,3,4-tetrahydroacridine) (1 eq), 1,2-diaminoethane (2 eq), phenol (1.5 g), and KI (50 mg) were carefully heated at $180{ }^{\circ} \mathrm{C}$ under an inert system for $4 \mathrm{~h}$ and then cooled at room temperature. The mixture was diluted with EtOAc and made basic with $10 \% \mathrm{NaOH}$ solution. The organic layer was washed with water and brine. The combined organic phases were dried over $\mathrm{Na}_{2} \mathrm{SO}_{4}$ and concentrated under reduced pressure to give the crude product. Purification was performed by column chromatography, eluent: $\mathrm{CH}_{2} \mathrm{Cl}_{2} / \mathrm{MeOH} / \mathrm{Et}_{3} \mathrm{~N}$ (7:1:1) to afford compound $\mathrm{X}$ as a brown oil, yield $68 \%$. 
${ }^{1} \mathrm{H}$ NMR (300 MHz, $\left.\mathrm{CDCl}_{3}, \delta \mathrm{ppm}\right): \delta 8.19\left(\mathrm{dd}, 1 \mathrm{H}, \mathrm{J}_{1}=8.0 \mathrm{~Hz}, \mathrm{~J}_{2}=1.6 \mathrm{~Hz}, \mathrm{H}-9\right)$, $8.06(\mathrm{~d}, 1 \mathrm{H}, \mathrm{J}=8.8 \mathrm{~Hz}, \mathrm{H}-12), 7.70$ (ddd, $\left.1 \mathrm{H}, \mathrm{J}_{1}=8.8 \mathrm{~Hz}, \mathrm{~J}_{2}=7.2 \mathrm{~Hz}, \mathrm{~J}_{3}=1.6 \mathrm{~Hz}, \mathrm{H}-10\right)$, $7.57\left(\mathrm{ddd}, 1 \mathrm{H}, \mathrm{J}_{1}=8.0 \mathrm{~Hz}, \mathrm{~J}_{2}=7.2 \mathrm{~Hz}, \mathrm{~J}_{3}=1.2 \mathrm{~Hz}, \mathrm{H}-11\right), 3.18$ (t, 2H, J=6.8 Hz, H-6), 3.04 (t, 2H, J=6.8 Hz, H-3), 1.97 (m, 4H, H-4 and H-5)

\section{Example of hybrid tacrine-chitosan synthesis:}

To an heterogeneous stirred mixture of Chitosan ( 1 equiv.) in a $0.12 \mathrm{M}$ solution of aq. acetic acid in methanol at final $\mathrm{pH}$ value of 5 , the tacrine isoselenocyanate $(0.7$ equiv.) was added under argon atmosphere at room temperature. The mixture was allowed to stand monitoring by TLC. After one week, the mixture was filtered and the filtrate was washed successively to give the corresponding selenoureidyl hybrid tacrinechitosan derivative as yellow solid.

IR (vmax): 3303, 2925, 2879, 1638, 1543, 1374, 1307, 1203, 1057, $1029 \mathrm{~cm}^{-1} ;{ }^{1} \mathrm{H}$ NMR with diffusion filter $\left(500 \mathrm{MHz}, \mathrm{AcDO}, \mathrm{D}_{2} \mathrm{O}\right): \delta 8.30(\mathrm{~m}$, HArTacrine), $4.91(1 \mathrm{H}$, m, H-1), 4.00-3.55 (5H, m, H-3, H-4, H-5, H-6 and H-6'), 3.26 (1H, s, H-2), $2.08(1 \mathrm{H}$, $\mathrm{s}, \mathrm{CH}_{3}(\mathrm{NAc}) ;{ }^{13} \mathrm{C} \mathrm{CP}-\mathrm{MAS}$ NMR $(150.9 \mathrm{MHz}, \delta \mathrm{ppm}): \delta 180.8(\mathrm{C}=\mathrm{Se}), 172.5(\mathrm{C}=\mathrm{O}$, NAc), 148.3-126.2 (C-Arom), 105.1 (C1), 82.2 (C4), 75.4 (C3 у C5), 60.6 (C6), 57.5 (C2), $23.7\left(\mathrm{C}-\mathrm{OCH}_{3}\right)$. DS (\%) (by ${ }^{13} \mathrm{C}$ CPMAS NMR): 3.5 .

\section{Results and discussion}

First aim was the synthesis of tacrine derivatives. It was carried out by two different methodologies:

The first methodology, methodology A, consists in the functionalization of commercial tacrine through the amino group. It was carried out by reaction of tacrine with different alkyl halides in the presence of different bases such as $\mathrm{NaOH}$, DIPEA, $\mathrm{NaH}$, etc (Scheme 1). However, the bad nucleophility of this aromatic amine led to bad yields or even no reaction in some cases. 
<smiles>Nc1c2c(nc3ccccc13)CCCC2</smiles>

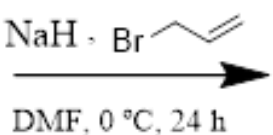<smiles>C=CCNc1c2c(nc3ccccc13)CCCC2</smiles>

$(31 \%)$<smiles>C=CCN(CC=C)c1c2c(nc3ccccc13)CCCC2</smiles>

$(15 \%)$<smiles>Nc1c2c(nc3ccccc13)CCCC2</smiles>

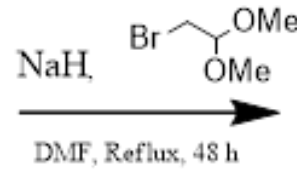<smiles>COC(CNc1c2c(nc3ccccc13)CCCC2)OC</smiles>

$(50 \%)$<smiles>Nc1c2c(nc3ccccc13)CCCC2</smiles><smiles>N#[W][W]</smiles><smiles>BrCCCCCNc1c2c(nc3ccccc13)CCCC2</smiles>

$(41 \%)$

Scheme 1. Syntesis of some tacrine derivatives by methodology a (1-5)

The shortage of derivatives that could be obtained and the poor yields led to opt for second approach, methodology B.

This second methodology consists in the formation of the tacrine skeleton by using anthranilic acid and cyclohexnone in the presence of phosphorus oxychloride giving 9chloro-1,2,3,4-tetrahydroacridine. ${ }^{5}$ Then, amino group would be introduced in the skeleton by a nucleophilic aromatic substitution using as reagent 1,2-diaminoethane. Finally, the amino group of the lateral chain would be used to obtain different tacrine derivatives with an adequate function to reacts with chitosan. (Scheme 2) 
<smiles>[R20]C([R6])[C@H](C)[C@@H]1CCCCC1=O</smiles><smiles>Clc1c2c(nc3ccccc13)CCCC2</smiles>

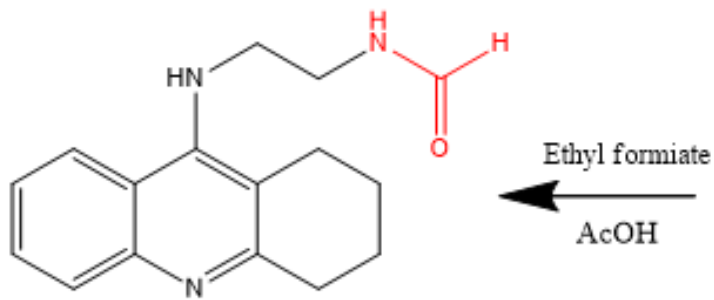
$(90 \%)$

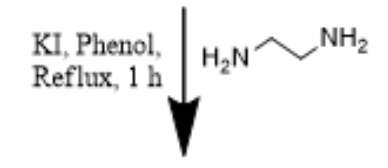<smiles>NCCNc1c2c(nc3ccccc13)CCCC2</smiles>

$(66 \%)$<smiles>O=CNCCNc1c2c(nc3ccccc13)CCCC2</smiles>
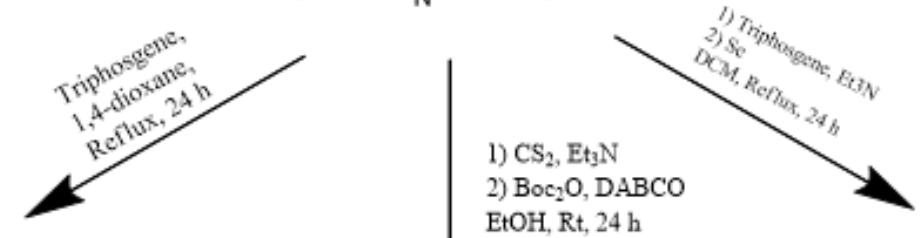

2) $\mathrm{Boc}_{2} \mathrm{O}, \mathrm{DABCO}$ $\mathrm{EtOH}, \mathrm{Rt}, 24 \mathrm{~h}$<smiles>O=[N+]([O-])CCNc1c2c(nc3ccccc13)CCCC2</smiles>

$(57 \%)$<smiles>CS(=O)(=O)CCNc1c2c(nc3ccccc13)CCCC2</smiles>

$(70 \%)$<smiles>CS(=O)(=O)CCNc1c2c(nc3ccccc13)CCCC2</smiles>

$(82 \%)$

Scheme 2. Synthesis of tacrine derivatives by methodology B

Once tacrine derivatives were obtained, they were linked to the biopolymer through amino group of chitosan obtaining different bridges between chitosan and tacrine, in the same way that other types of chitosan derivatives have been obtained by our research group. ${ }^{6,7}$ 
Starting polymeric material was characterized to obtain the degree of deacetylation $(\mathrm{DD}=84 \%)$ and molecular weight $\left(\mathrm{Mw}=87875 \mathrm{~g} \cdot \mathrm{mol}^{-1}\right)$. Both parameters are the essential fingerprint for polymers characterization. For DD calculation, relative integrals of proton in ${ }^{1} \mathrm{H}-\mathrm{NMR}$ spectra were used. Mw was determined by using HPLC-SEC technique.

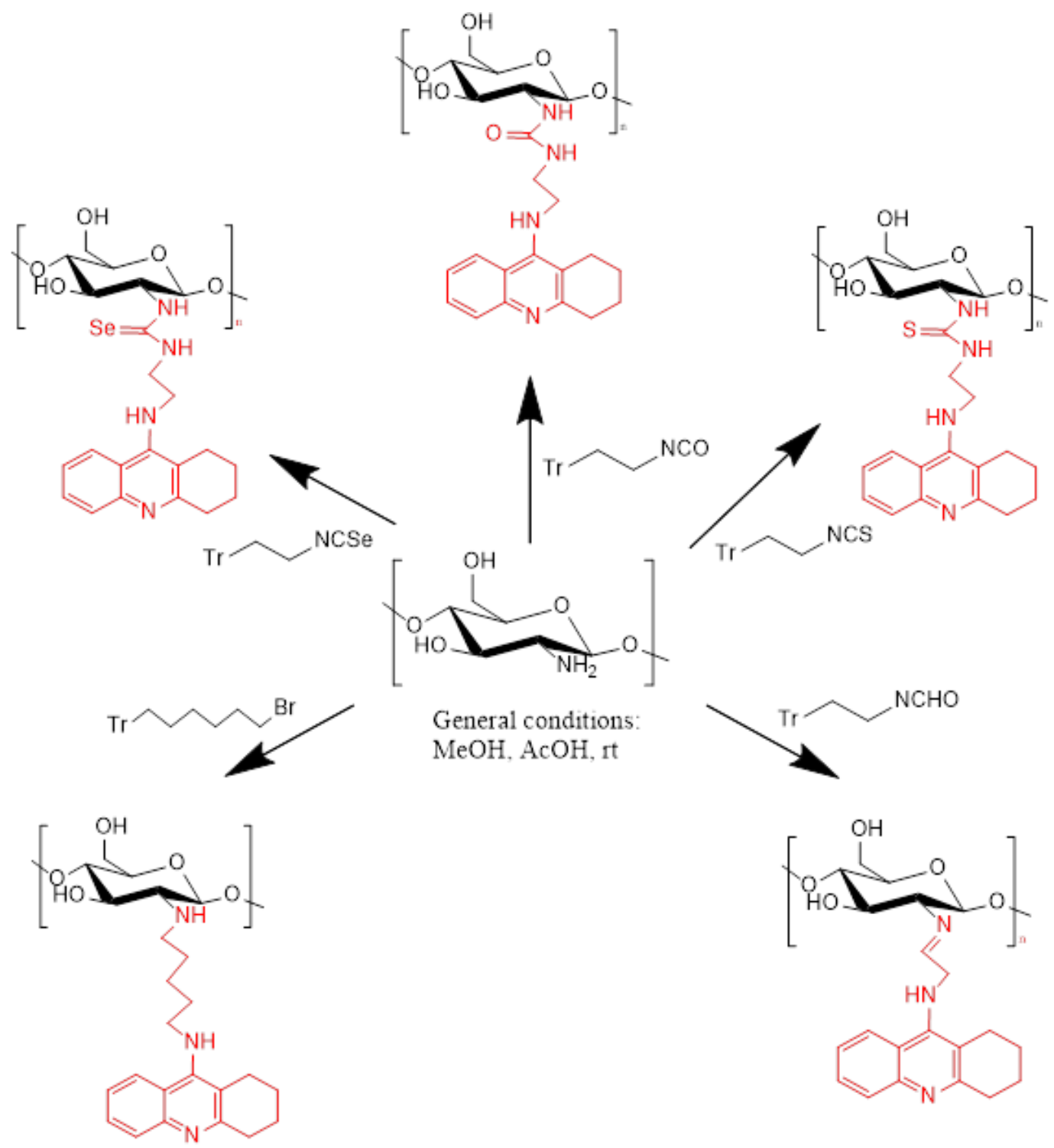

Scheme 3. Binding of tacrine derivatives to the biopolymer 
Characterization of hybrids tacrine-chitosan was realized by using ${ }^{1} \mathrm{H}$ NMR and ${ }^{13} \mathrm{C}$ CPMAS NMR techniques. An effective attachment to chitosan backbone has been corroborated on the basis of diffusion NMR experiments.

In ${ }^{1} \mathrm{H}$ NMR spectra for all obtained chitosan derivatives, the typical signals corresponding to chitosan backbone were observed. When reaction between chitosan and tacrine derivatives take place new peaks for aromatic protons were observed.

Additionally, ${ }^{13} \mathrm{C}$ CPMAS NMR spectra for all obtained chitosan derivatives. For instance, for hybrid tacrine-chitosan with selenourea bond show next to the typical signals corresponding to Chitosan backbone the $\mathrm{C}=\mathrm{Se}$ signal at $179-180 \mathrm{ppm}$ close to the $\mathrm{C}=\mathrm{O}$ band of Chitosan amide moiety $(173 \mathrm{ppm})$ and those corresponding to the aromatic carbons.

\section{Conclusions}

New Tacrine derivatives have been obtained by two different methodologies. However, methodology B could be a better option in order to obtain a library of Tacrine derivatives. Furthermore, new chitosan derivatives have been synthesized by reaction of the biopolymer with the different functionalized Tacrine derivatives with DS from 0.84 to $3.50 \%$. Inhibition capacity of Acethylcholinesterase and hepatotoxicity of these new compounds must be studied in the nearest future.

\section{Acknowledgements}

The authors thank the Junta de Andalucía (2011/FQM-142); Spanish Ministerio de Economía, Industria y Competitividad (MINECO), Spain (ProjectCTQ2016-78703-P); A. J. Galera-Carrillo also thanks Universidad de Sevilla (PEJUS-2, 2017-2-EJ-070) for funding support. The authors also thank the CITIUS, Universidad de Sevilla, for the facilities. 


\section{References}

1. Pokhrel, S., Yadav, P.N., Andhikari, R. Applications of chitin and chitosan in industry and medicinal science: a review, Nepal Journal of Science and Technology 2016, 16 99-104.

2. Prasanthi , N.L., Roy , H., Jyothi , N., Vajrapriya ,V.S. American Journal of Pharmtech Research 2016, 6, 41-51

3. Zafrilla, P., Mulero, J., Xandri, J.M., Santo, E., Caravaca, G., Morillas, J. M. Oxidative Stress in Alzheimer Patients in Different Stages of the Disease, Current Medicinal Chemistry 2006, 13: 1075.

4. Tumiatti, V., Minarini, A., Bolognesi, M.L., Milelli, A., Rosini, M., Melchiorre, C. Tacrine Derivatives and Alzheimers Disease, Current Medicinal Chemistry 2010, 17: 1825 .

5. Bornstein, J., Eckroat, T., Houghton, J., Jones, C., Green, K., GarneauTsodikova, S. Tacrine-mefenamic acid hybrids for inhibition of acetylcholinesterase. Med. Chem. Commun. 2011. 2.

6. Jatunov, S.; Franconetti, A.; Prado-Gotor, R.; Heras, A.; Mengíbar, M.; CabreraEscribano, F. Carbohydrate Polymers 2015, 123, 288-296.

7. De Gonzalo, G.; Franconetti, A.; Fernández, R.; Lassaleta, J. M.; CabreraEscribano, F. Carbohydrate Polymers 2018, 199, 365-374. 